\title{
Plasma free amino acid profiles in growing chickens fed soyabean meal supplemented with DL-methionine
}

\author{
I. Fernández-Fígares ${ }^{1}$, R. Nieto, C. Prieto and J.F. Aguilera
}

\author{
Animal Nutrition Department, Experimental Station Zaidin, \\ Spanish Council for Scientific Research (CSIC) \\ Camino del Jueves s/n, Armilla, 18100 Granada, Spain
}

(Received 27 February 2004; revised version 17 March 2005; accepted 18 March 2005)

\begin{abstract}
Two experiments were carried out to study the effect of supplementing soyabean meal with methionine, at four different protein levels, on plasma free amino acids of growing chickens. Two blood sampling methods were used: single bleeding, where each bird is bled once (Experiment 1) and serial bleeding where each bird is bled consecutively every four days (Experiment 2). Following a randomized paired-feeding design based on metabolic body weight $\left(\mathrm{W}^{0.75}\right), 11$-days old White Rock male broilers were allocated, for an experimental period of 20 days, to one of two isoenergetic, semisynthetic diets containing 60,120,180 and $240 \mathrm{~g}$ protein $/ \mathrm{kg}$ diet. All diets were based on soyabean meal either unsupplemented or supplemented with $2 \mathrm{~g} / \mathrm{kg}$ DL-methionine. Thirty-two and eight chickens were used in Experiments 1 and 2, respectively. Interactions between sampling method and either supplementation or protein level were not significant for most essential amino acids. Methionine supplementation of the soyabean meal diets elicited an increase of methionine and a significant decrease of threonine, valine, leucine and lysine in plasma, irrespective of sampling method or protein level (except no effect of methionine supplementation at $24 \%$ CP for plasma free lysine), while basic and aromatic amino acids remained unaltered. Increasing dietary protein level four fold augmented plasma levels of arginine, threonine, valine and methionine, irrespective of sampling method or supplementation effects. Threonine was the most sensitive amino acid to the effect of dietary protein level, increasing its concentration 3 fold.

In conclusion, multiple and single bleeding methodologies were both sensitive to evaluate the improvement of dietary protein quality after methionine supplementation.
\end{abstract}

KEY WORDS: plasma amino acids, soyabean protein, methionine, chicken

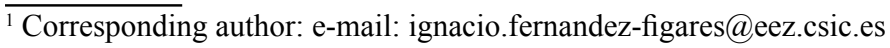




\section{INTRODUCTION}

Attempts to establish a direct relationship between the free amino acid concentrations in plasma and the amino acid profile of the protein ingested, as a predictor of the availability of amino acids in dietary proteins, have yielded conflicting results. A relationship between amino acid dietary supply and free amino acid concentration in systemic blood has been found by several authors (Zimmerman and Scott, 1965; Jansen et al., 1986) whereas other studies found no clear evidence for such a relationship (Waterlow and Fern, 1981; Hagemeister et al., 1990). The utilization of dietary amino acids is affected by numerous dietary (energy supply, vitamins, minerals, amino acid imbalance, anti-nutritional factors) and non-dietary (gender, genotype, thermal environment) factors, which are sometimes difficult to control experimentally, what might explain the inherent shortcomings (Hurrell and Carpenter, 1984).

Plasma free amino acids proved to be useful for identifying the most limiting amino acids in diets with different protein sources fed to growing chickens at high or low protein level (Prieto et al., 1994). In a previous experiment (Fernández-Fígares et al., 1993) where growing chickens were fed on isoenergetic high and low protein diets of widely different essential amino acid profiles, plasma concentration of the most limiting amino acids in the diets paralleled their rank in dietary protein. Most studies found through the literature deal with proteins of quite different amino acid profiles and do not consider the possible confounding effect of the level of protein. There is a lack of information concerning the use of postprandial plasma amino acid concentrations as an index of adequate supplementation of protein sources with their limiting amino acids at widely different protein levels. We had previously (Fernández-Fígares et al., 1997) evaluated differences in dietary protein quality through changes in plasma, muscle and liver free amino acid levels. The aim of the present study is to use the postprandial plasma amino acid levels to evaluate the quality of dietary protein when it is supplemented with an amino acid, at different protein contents. Two different sampling methods were compared in an attempt to decrease the number of experimental units.

\section{MATERIAL AND METHODS}

\section{Diets}

Eight semisynthetic diets based on soyabean meal as the sole source of protein, supplemented or not with $2 \mathrm{~g} / \mathrm{kg}$ DL-methionine, at four levels of crude protein $(60,120,180$ and $240 \mathrm{~g} / \mathrm{kg}$ ), were formulated (Table 1). Diets were isoenergetic (14.5 kJ ME per g DM). 
鰥

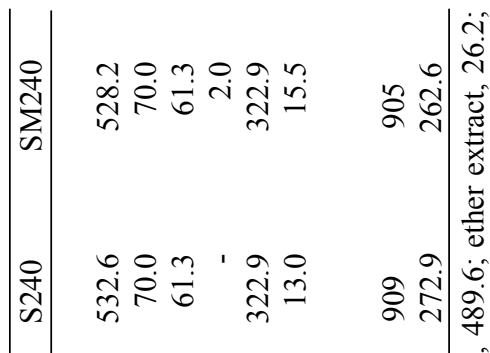

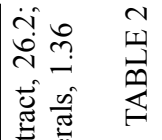

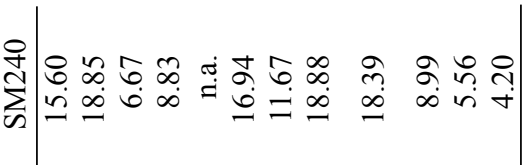

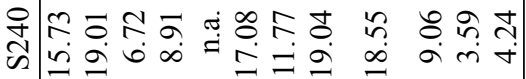
齐
至
๙

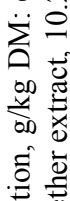

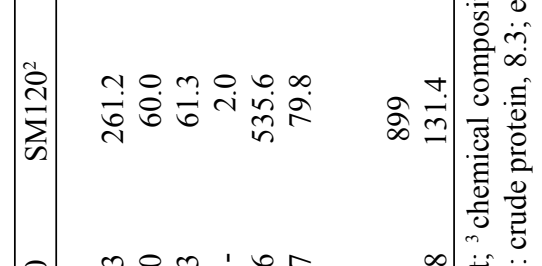

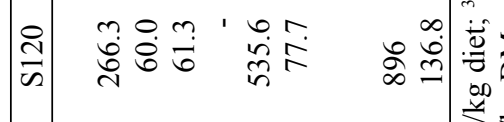

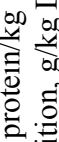
放 要

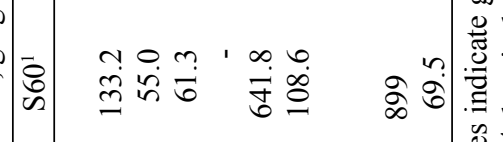

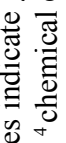
吾

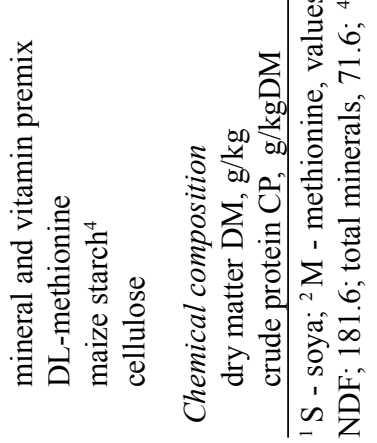

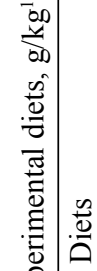

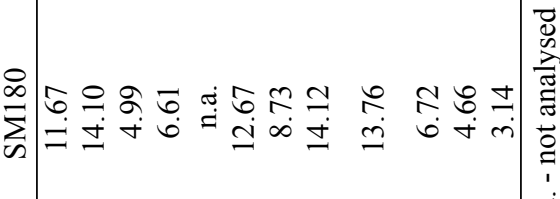
至

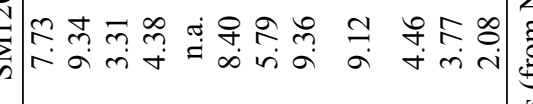

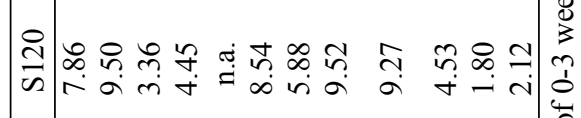
隹|

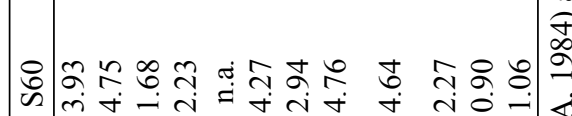

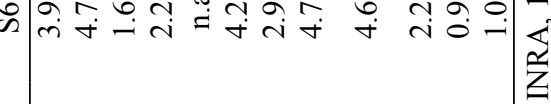

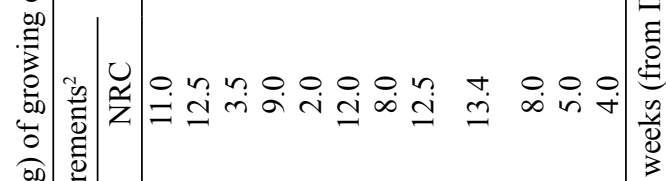
क्षि.

咅

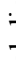


The amino acid requirements of growing chickens and the amino acid composition of the experimental diets are shown in Table 2.

\section{Experimental design}

Experiment 1 (single blood sampling). Thirty two White Rock male broilers (1-day-old) were raised in batteries at $30^{\circ} \mathrm{C}$ and given a commercial starter diet for 10 days. Then they were randomly divided into 8 groups of four birds per group on a weight basis (mean liveweight $178 \pm 2.7 \mathrm{~g}$ ) and individually kept in metabolism cages under controlled temperature $\left(26 \pm 1^{\circ} \mathrm{C}\right)$ and photoperiod ( $12 \mathrm{~h}$ light: $12 \mathrm{~h}$ dark) conditions. Following a change-over design (Figure 1), each group of birds was given, every four days, each of four levels of protein $(60,120,180$ or $240 \mathrm{~g} / \mathrm{kg}$ ), either unsupplemented or supplemented with DL-methionine (Table 1).

Within diets of the same protein quality and after an adaptation period of 4 days, one chicken from each group of four was selected at random, sedated with ketamine-rompun (10.0 and $3.0 \mathrm{mg} / \mathrm{kg}$; Warner Lambert Co. Morris Plains, NJ, USA; Bayer, Laverkusen, Germany) and a blood sample was taken by heart puncture between 1 and $2 \mathrm{~h}$ after the first morning meal (Prieto et al., 1994). Heart puncture was performed using a syringe and a $50 \mathrm{~mm} 20$ gauge needle. The syringe was rinsed with undiluted heparine immediately before drawing $1 \mathrm{ml}$ blood. The remaining birds were allocated to the following treatment for another period of 4 days.

Experiment 2 (serial sampling). It was performed simultaneously to Experiment 1 and animals were within the same room and conditions: eight White Rock male broilers (1-day-old) of the same batch used in Experiment 1 were raised in batteries and fed a commercial starter diet as previously explained. Then they were randomly assigned the afore-mentioned 8 treatments. Blood samples $(1 \mathrm{ml})$ were collected by heart puncture every 4 days for each chicken (Figure 1). The volume of blood extracted each time represented $0.56-0.25 \%$ (from period I to IV) of body weight. Experimental design was similar to the Experiment 1 except that, after bleeding, each bird was subsequently allocated to the following protein level treatment for another period of 4 days and continued this schedule until the end of the experiment. According to this schedule four replicates (one per time period) of each level of protein per diet were obtained.

Within each protein level birds on diets S and SM were paired-fed. Continuous feeding was achieved by fractionating feed allowance into six identical rations offered to the birds every two hours, starting at $9.00 \mathrm{~h}$. Feed was voluntarily consumed at about the same rate in both control and supplemented birds. Water was provided ad libitum. The Institutional Bioethics Committee of CSIC approved the care and treatment of all birds. 


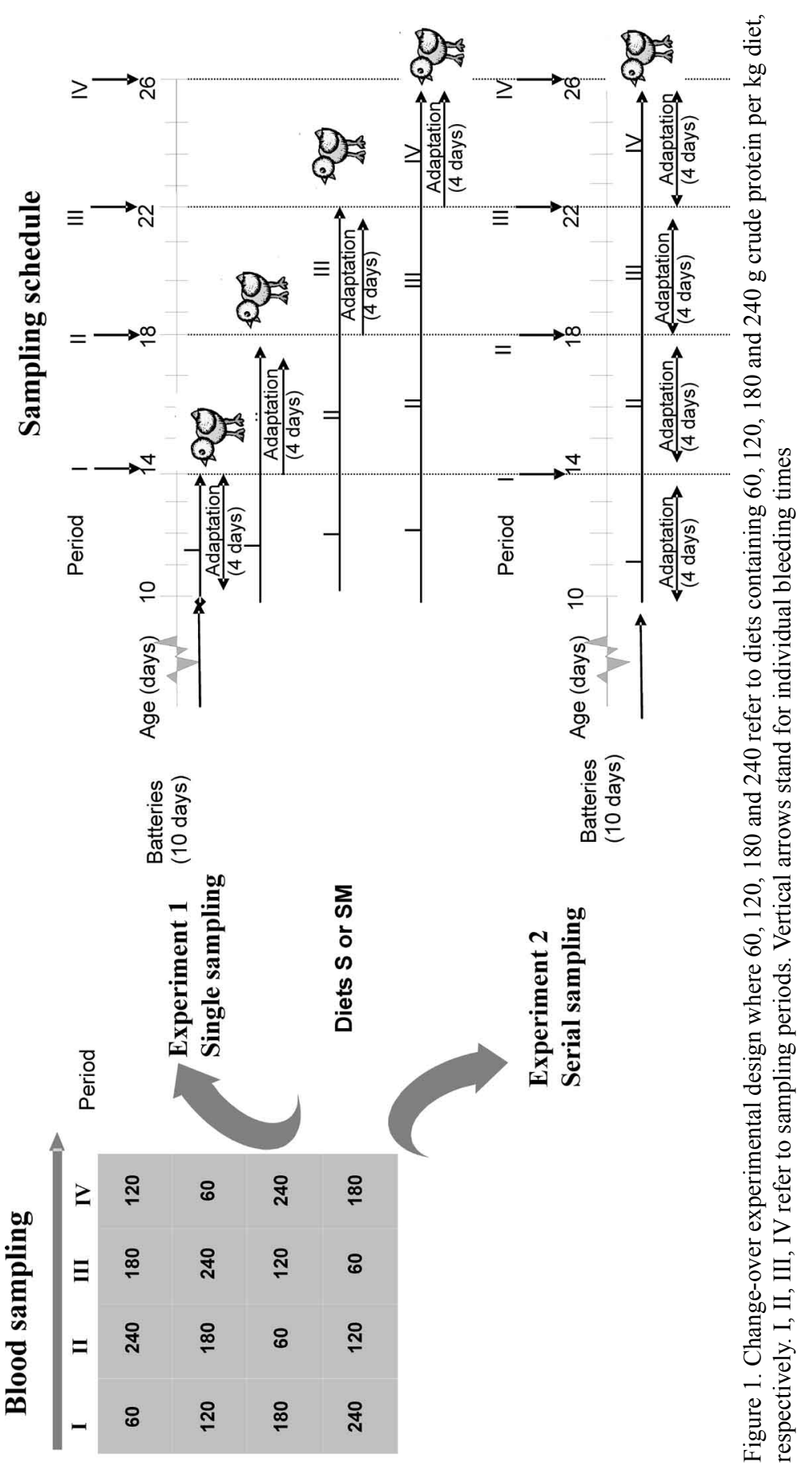




\section{Analytical procedure}

Heparinized blood samples were centrifuged at $1500 \times \mathrm{g}$ for $15 \mathrm{~min}$ to obtain plasma, and stored at $-20^{\circ} \mathrm{C}$ until amino acid analysis. Norleucine $(40 \mathrm{mM}$ in $0.1 \mathrm{mM} \mathrm{HCl}$ ) was added to plasma as internal standard and samples were then deproteinized by ultrafiltration (Ultrafree MC microcentrifuge device, Millipore P/N SK 1P44V7). Plasma free amino acids and dietary amino acids (previously hydrolysed) were determined by high performance liquid chromatography according to the Waters Pico Tag method with pre-column derivatization with phenylisothiocianate (Cohen et al., 1989), as previously described (FernándezFígares et al., 1993). Analysis of cysteine and methionine in hydrolysates was made after performic acid oxidation and determined as cysteic acid and methionine sulphone, respectively (Moore, 1963). A Waters System Interface Module and Maxima 820 Chromatography software (Dynamic Solution, Division of Millipore) were used for gradient control and data processing.

\section{Statistical analysis}

The experimental data were analysed as 2 (sampling method (MD): single or serial bleeding for each bird) $\times 2$ (supplementation $(\mathrm{SU})$ : control or supplemented, diets $\mathrm{S}$ or SM, respectively) $\times 4$ (protein level (PL): 60, 120, 180 and $240 \mathrm{~g} \mathrm{CP} / \mathrm{kg}$ diet) factorial design. The data were subjected to repeated measures ANOVA followed by multiple range tests by means of a computer package (STATGRAPHICS Plus for Windows Version 5.1, Manugistics Inc., Rockville, MD).

\section{RESULTS}

Mean values of feed intake and growth performance are presented in Table 3. Sampling method had no influence on feed intake or growth performance. Body weight gain $(\mathrm{g} / \mathrm{d})$ and weight gain relative to protein intake increased $(\mathrm{P}<0.001)$ as soya diets were supplemented with DL-methionine. As a pairfed design was used, there were no differences in dry matter or protein intake among supplemented or unsupplemented diets. Concerning the level of protein in the diets, body weight gain relative to protein intake increased with increasing dietary protein concentration from 60 to $120 \mathrm{~g} / \mathrm{kg}$ and then was maintained, while daily body gain significantly increased $(\mathrm{P}<0.001)$ with increasing the amount of protein consumed. Dry matter intake increased with increasing dietary protein concentration up to $180 \mathrm{~g} / \mathrm{kg}$ protein $(\mathrm{P}<0.001)$. For all of the parameters analysed interactions were not significant. 


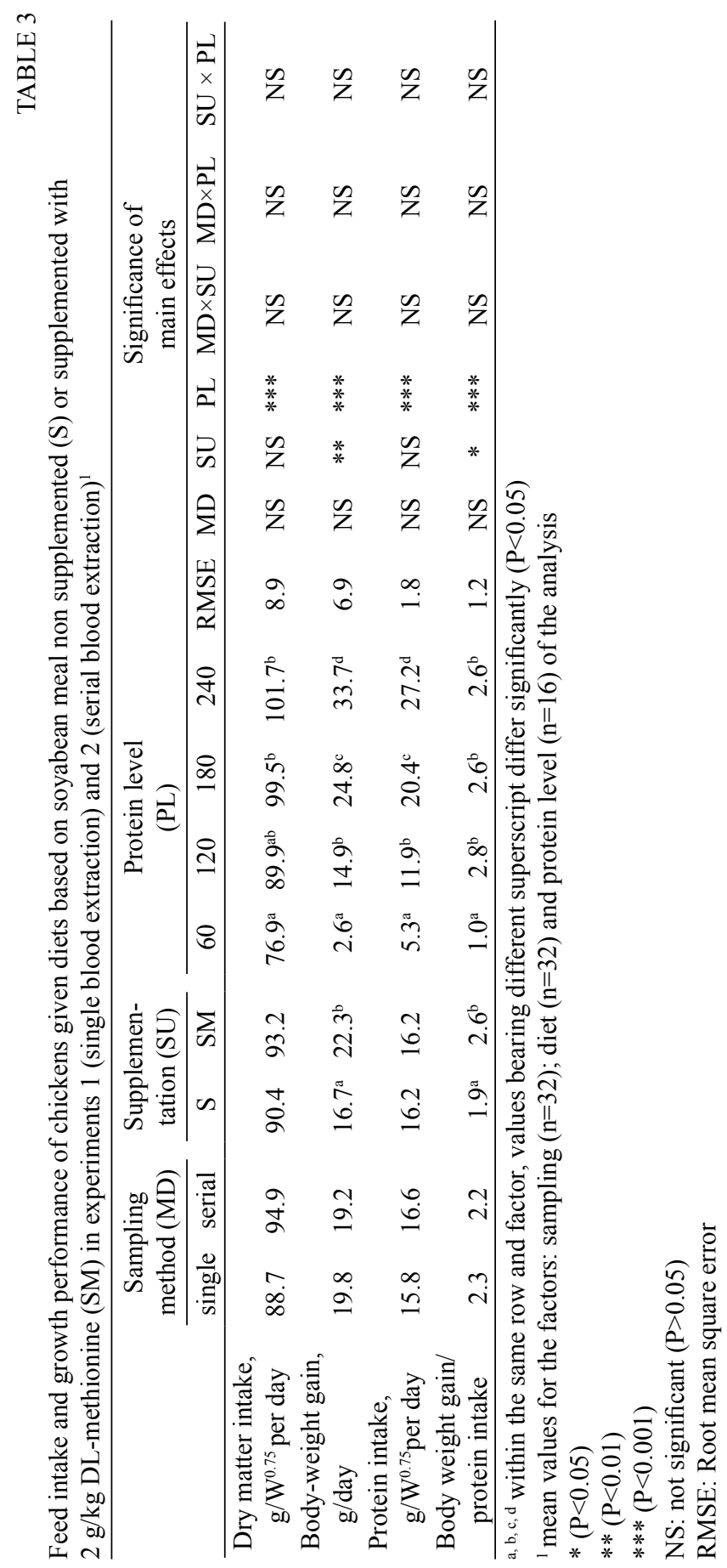




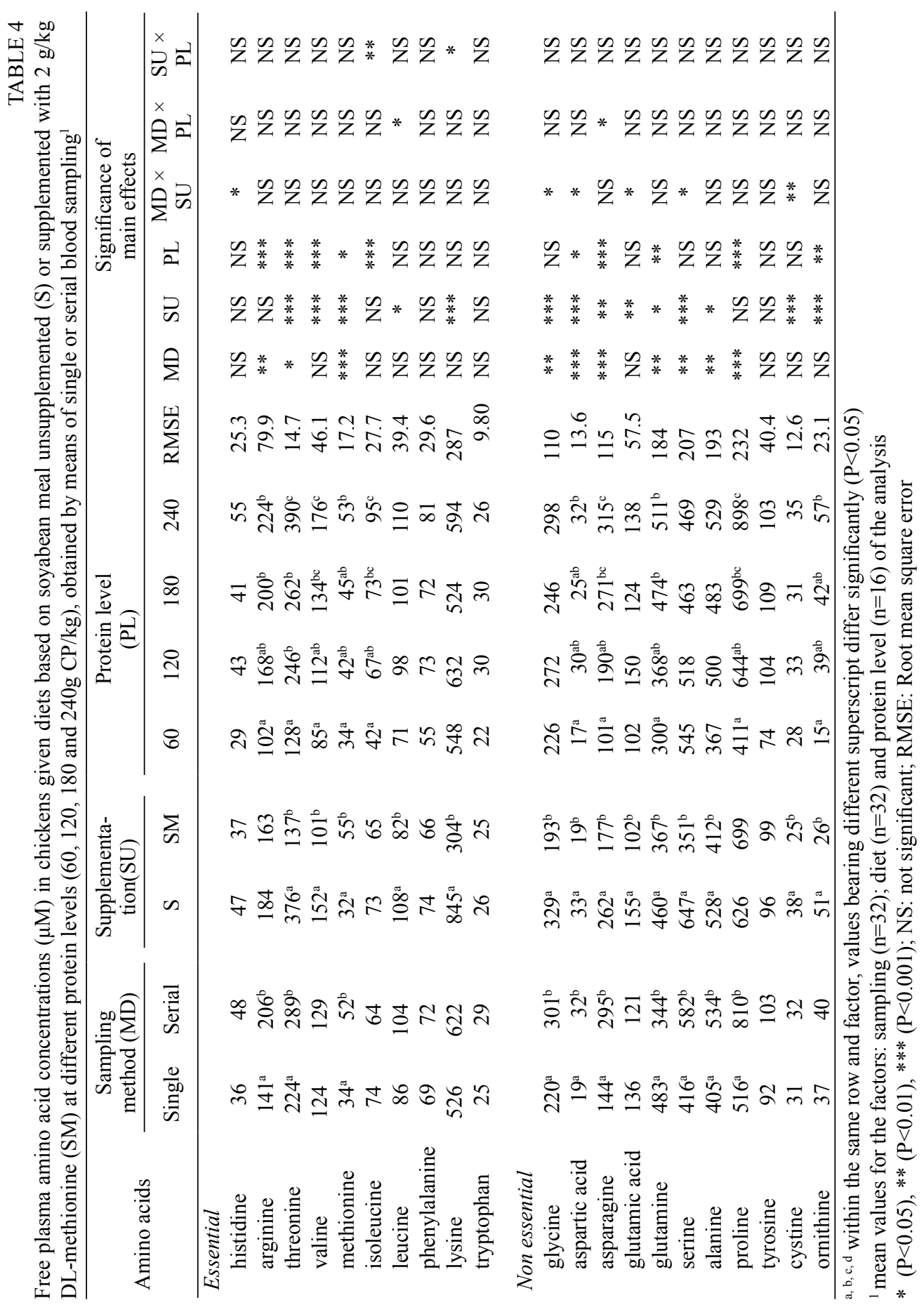


Free amino acid concentrations in plasma of birds fed soyabean meal diets at four protein levels and bled once (single sampling) or four times consecutively over time (serial sampling) are shown in Table 4. There was a trend towards higher plasma amino acid concentrations when serial sampling was used, which was significant for arginine, threonine and methionine, no matter diet or protein level used. MD x PL interaction was significant for leucine; differences in plasma leucine concentration were significant only when serial sampling was used. Similarly, $\mathrm{MD} \times \mathrm{SU}$ interaction was statistically significant for histidine; the lower plasma histidine level found when chickens were fed diets supplemented with DL-methionine, was significant only when serial blood sampling was used.

The level of threonine, valine and leucine in plasma of chickens fed with methionine supplemented soya diets significantly $(\mathrm{P}<0.001)$ decreased while arginine, tryptophan and phenylalanine remained unchanged with no significant interactions between factors. Lysine significantly decreased as well, although interactions between factors existed $(\mathrm{P}<0.05)$. Study of the interactions (data not shown) revealed that at the highest level of protein, plasma lysine did not significantly decrease after methionine supplementation of the diet. Plasma level of methionine significantly increased in birds fed on methionine supplemented diets (SM) through all of the protein levels, no matter the blood sampling method used.

An increase of plasma levels of most amino acids on increasing dietary protein content was found. Statistically significant differences were achieved for arginine, threonine, valine, methionine and isoleucine, although a SU $\times$ PL interaction was significant for isoleucine; the augmented isoleucine levels encountered when chickens were fed increasing amounts of protein was statistically significant only for chickens fed DL-methionine supplemented diets.

\section{DISCUSSION}

The concentration of free amino acids in blood plasma is affected by various factors, including the level and pattern of amino acids supplied by the diet, the status of the amino acid transport systems in the various organs and the pathophysiological condition of the organism. In general, the size of an amino acid pool is approximated by its free amino acid concentration (Waterlow et al., 1978). Caution must be applied when relating free amino acid concentrations to other aspects of amino acid metabolism; however concentration differences under controlled circumstances provide a measure of the "net effect" of various changes.

In the present study differences in biological value of dietary protein fed to growing chickens were established supplementing soyabean meal with the first limiting amino acid, at four different protein levels, and resulting changes in 
postprandial plasma amino acids attributable to the differing quality of the protein were looked for. Two blood sampling techniques were compared, single (one sample per chicken) or serial (several samples per chicken). Our previous studies with growing chickens (Prieto el al., 1994) showed that postprandial increase in plasma essential amino acids peaked at $1 \mathrm{~h}$, remained elevated up to $5 \mathrm{~h}$ and then declined, which means that plasma samples obtained in the present experiments were within that plateau.

A 4 days period of adaptation to diet was considered sufficient to eliminate the carry-over effect between different levels of protein. In this respect, in a previous experiment with growing chickens (Fernández-Fígares et al., 1996) and following a similar design, this adaptation period proved to be adequate to show significant changes in the excretion of $\mathrm{N}$ compounds (total $\mathrm{N}$, uric acid and ammonia) as a result of supplementing with DL-methionine a semisynthetic diet based on soyabean meal as a single source of protein. Also in rats given low-protein or adequate-protein diets based on casein supplemented with individual branchedchain amino and $\alpha$-ketoacids, Block and Harper (1991) found that the patterns of plasma and brain amino acid concentrations were similar at 2, 6 and 10 days of consumption of the experimental diets.

Compared with the recommended amino acid requirements (INRA, 1984; NRC, 1994), the experimental diets containing 60 and $120 \mathrm{~g} \mathrm{CP} / \mathrm{kg}$ diet supplied insufficient amounts of all essential amino acids. The diets with $180 \mathrm{~g} \mathrm{CP} / \mathrm{kg}$ diet were clearly deficient in valine, methionine and cystine and those with $240 \mathrm{~g} \mathrm{CP} /$ $\mathrm{kg}$ diet provided an excess of all essential amino acids except for valine (supplied in adequate amount) and sulphur containing amino acids which were deficient in diet S24 and adequate in diet SM24. Supplementation with DL-methionine improved all growth parameters.

Several studies have dealt with the nutritional significance of plasma amino acid levels (Johnson and Anderson, 1982; Sarwar et al., 1983) as a biochemical parameter to ascertain the quality of dietary protein in an effort to overcome the disadvantages of classical balance methods (Pellet and Young, 1980), without conclusive results. Direct relationships of diet to blood amino acid levels are obscured because of the complexity of protein metabolism. Small intestine and liver play a crucial role in the distribution of nutrients to the periphery. Nevertheless, Song et al. (2001) demonstrated that hepatic extraction rate of essential amino acids in chicks in vivo was significant only for methionine, phenylalanine and histidine, and negligible for the rest of essential amino acids. Plasma amino acids determined early postprandially are probably more reflective of available amino acids from the diet for protein synthesis than if they are determined later. In that sense, postprandial plasma amino acid concentrations have been used extensively as an index of the nutritional value of dietary proteins in preterm infants (Moro et al., 1999). 
Method of sampling. In the present experiments, birds submitted to serial bleeding had significantly higher plasma concentration of arginine, threonine and methionine, than birds bled only once. The volume of blood extracted represented only 5.4-2.9\% (from period I to IV, respectively) of total blood in chickens of that age (Medway and Kare, 1959) which we think is negligible considering that the animals have free access to water and four days to recover between extractions. Absolute values for both methods were within the range of literature data for growing chickens (Zimmerman and Scott, 1965; Fernández-Fígares et al., 1993, 1997). Furthermore, for essential amino acids, the interaction $\mathrm{MD} \times \mathrm{SU}$ was significant only for histidine, and $\mathrm{MD} \times \mathrm{PL}$ was significant only for leucine, meaning that the effect of supplementation and protein level was independent of the sampling method used.

Study of the MD $\times$ SU interaction showed that differences in plasma amino acid levels when birds fed supplemented diets were compared to controls were of greater magnitude if serial bleeding was used as opposed to single bleeding. Similarly, differences in plasma amino acid concentrations of birds fed graded levels of protein were greater in chickens submitted to serial bleeding.

Supplementation with DL-methionine. Methionine supplementation of soya diets to improve its protein quality sharply increased chicken plasma methionine concentration at all protein levels assayed, no matter which sampling method was used. Similarly to our current results, supplementation with methionine in diets deficient in this amino acid led to a rise in plasma free methionine in rats (Pion, 1973) and chickens (Fernández-Fígares et al., 1997). Plasma concentrations of valine, threonine, leucine and lysine significantly decreased when chickens were fed with methionine supplemented diets as compared to controls. It has been postulated in chickens that efficient utilization of dietary protein and relatively low levels of amino acids in the plasma are fairly closely related (Hewitt and Lewis, 1972), and reduced plasma amino acids with amino acid supplementation is due to improved amino acid balance which stimulated rate of weight gain and caused removal of amino acids for protein synthesis. Studies with young pigs (Bertolo et al., 1999) also support the supposition that higher protein synthesis rates result in lower free amino acid concentrations for several essential amino acids. Nieto et al. (1994) studied the effect of supplementation a soyabean meal diet with DL-methionine on fractional rates of protein synthesis and degradation in the skeletal muscle and liver of growing chickens. Amino acid supplementation decreased protein degradation rates in muscle and liver, while protein synthesis remained apparently unaffected. Lower muscle and liver protein degradation rates could explain the decreasing plasma free amino acid concentrations found when methionine supplemented diets were offered.

Effect of protein level. We have found that plasma concentration of most amino acids, essential and non essential, increased on increasing protein intake from 60 
to $240 \mathrm{~g}$ crude protein per $\mathrm{kg}$. Statistically significant differences, independent of method of sampling and supplementation, were found for arginine, threonine, valine and methionine. Quantitatively, plasma threonine concentration of birds fed on the highest protein level $(240 \mathrm{~g} \mathrm{CP} / \mathrm{kg})$ was 3-4 fold higher than the one of birds fed on the lowest protein level $(60 \mathrm{~g} \mathrm{CP} / \mathrm{kg})$. Different response curves of the plasma amino acid concentrations to the dietary protein level suggest that these are a reflection of the metabolic activities of the individual amino acids and also that plasma amino acid concentrations are precisely regulated. In that respect, it has been shown that plasma concentration of lysine and threonine, which are relatively resistant to deamination (Watanabe et al., 1997), are frequently higher than those of the rest of amino acids. Among the essential amino acids, threonine and lysine concentration were the highest in our experiments. Similarly to our findings, body pools of most amino acids increased in rats immediately after they had consumed a meal, and the increase was proportional to the protein content of the diet (Dixon and Harper, 1984).

\section{CONCLUSIONS}

Data obtained in the present experiment indicate that plasma free amino acid profile determined early postprandially in chickens is sensitive to the supplementation of soya protein with its first limiting amino acid at widely different protein contents. Similar trends were obtained using single and serial blood sampling. However, extrapolation of data to the range of protein qualities encountered in typical practical diets needs further study.

\section{ACKNOWLEDGMENTS}

We are greatly indebted to Mrs. E. Colmenero for skillful animal care and technical assistance and Dr L. Lara for statistical analysis.

\section{REFERENCES}

Bertolo R.F.P., Chen C.Z.L., Pencharz P.B., Ball R.O., 1999. Intestinal atrophy has a greater impact on nitrogen metabolism than liver by-pass in piglets fed identical diets via gastric, central venous or portal venous routes. J. Nutr. 129, 1045-1052

Block K.P., Harper A.E., 1991. High levels of dietary amino and branched-chain $\alpha$-keto acids alter plasma and and brain amino acid concentrations in rats. J. Nutr. 121, 663-671

Cohen S.A., Meys M., Tarvin T.L., 1989. The Pico-Tag Method. A Manual of Advanced Techniques for Amino Acid Analysis. Millipore Corporation. Bedford, Massachusets, pp. 123 
Dixon J.L., Harper A.E., 1984. Effects on plasma amino acid concentration and hepatic branchedchain alfa-keto acid dehydrogenase activity of feeding rats diets containing 9 or $50 \%$ casein. J. Nutr. 114, 1025-1034

Fernández-Fígares I., Lachica M., Pérez L., Nieto R., Aguilera J.F., Prieto C., 1993. The effect of dietary protein quality on free amino acids in plasma, muscle and liver of growing chickens. Anim. Prod. 57, 309-318

Fernández-Fígares I., Nieto R., Aguilera J.F., Prieto C., 1996. The use of the excretion of nitrogen compounds as an indirect index of the adequacy of dietary protein in chickens. Anim. Sci. 63, 307-314

Fernández-Fígares I., Prieto C., Nieto R., Aguilera J.F., 1997. Free amino acid concentrations in plasma, muscle and liver as indirect measures of protein adequacy in growing chickens. Anim. Sci. 64, 529-539

Hagemeister H., Scholz-Ahrens K.E., Schulte-Coerne H., Barth C.A., 1990. Plasma amino acids and cholesterol following consumption of dietary casein or soy protein in minipigs. J. Nutr. 120, $1305-1311$

Hewitt D., Lewis D., 1972. The effect of dietary lysine level, restriction of feed intake and sampling time on the levels of amino acids in the blood of chicks. Brit. Poultry Sci. 13, 387-398

Hurrell R.E., Carpenter K.J., 1984. The estimation of available lysine in foodstuffs after Maillard reactions. In: C. Botella (Editor). Nestlé Research News 1982/83, Lausanne (Switzerland). Nestlé Products Technical Assistance Co. Ltd., Technical Documentation Center, pp. 78-86

Institut National de la Recherche Agronomique, 1984. L'Alimentation des Animaux Monogastriques: Pork, Lapin, Volailles. INRA, Paris

Jansen G.R., Schibly M.B., Masor M., Sampson D.A., Longenecker J.B., 1986. Free amino acid levels during lactation in rats: effects of protein quality and protein quantity. J. Nutr. 116, 376-387

Johnson K.J., Anderson G.H., 1982. Prediction of plasma amino acid concentrations from diet amino acid content. Amer. J. Physiol. 243, R99-R103

Medway W., Kare M.R., 1959. Water metabolism of the growing domestic fowl with special reference to water balance. Poultry Sci. 38, 631- 637

Moore S., 1963. On the determination of cystine as cysteic acid. J. Biol. Chem. 238, 235-237

Moro G., Minoli I., Boehm G., Georgi G., Jelinek J., Sawatzki G., 1999. Postprandial plasma amino acids in preterm infants: influence of the protein source. Acta Paediat. 88, 885-889

National Research Council, 1994. Nutrient Requirements of Poultry. $9^{\text {th }}$ revised Edition. National Academy Press, Washington, DC

Nieto R., Palmer R.M., Fernández-Fígares I., Pérez L., Prieto C., 1994. Effect of dietary protein quality, feed restriction and short-term fasting on protein synthesis and turnover in tissues of the growing chicken. Brit. J. Nutr. 72, 499-507

Pellet P.L., Young V.R., 1980. Nutritional Evaluation of Protein Foods. United Nations University. Tokyo

Pion R., 1973. The relationship between the levels of free amino acids in blood and muscle and the nutritive value of proteins. In: J.E.G. Porter, B.A. Rolls (Editors). Protein in Human Nutrition. Academic Press, New York, pp. 329-338

Prieto C., Aguilera J.F., Lachica M., Fernández-Fígares I., Pérez L., Nieto R., Ferrando G., 1994. The use of plasma free amino acids for predicting the limiting amino acid(s) in diets for chickens. Anim. Feed Sci. Tech. 47, 151-164

Sarwar G., Peace R.W., Botting H.G., 1983. Validity of rat plasma amino acids in predicting first limiting amino acids in protein mixtures. Nutr. Rep. Int. 28, 613-620

Song Z., Beers K., Dibner J.J., Vázquez-Añón M., McNew R., Bottje W., 2001. The hepatic extraction of plasma free amino acids and response to hepatic portal venous infusion of methionine sources in anesthetized SCWL males (Gallus domesticus) Comp. Biochem. Physiol. Part B 130, 237-250 
Watanabe R., Iizuka T., Kokawa K., Yamamoto A., Ishibashi T., 1997. Effects of dietary threonine levels on the tissue amino acid concentration and threonine metabolic enzyme activity in laying hens. Anim. Feed Sci. Tech. 68, 529-536

Waterlow J.C., Fern E.B., 1981. Free amino acid pools and their regulation. In: J.C. Waterlow, J.M.L. Stephen (Editors). Nitrogen Metabolism in Man. Applied Science Publishing Co., London, pp. 1-16

Waterlow J.C., Garlick P.J., Millward D.J., 1978. Free amino acids. In: J.C. Waterlow, P.J. Garlick, D.J. Millward (Editors). Protein Turnover in Mammalian Tissues and in the Whole Body. Elsevier/North-Holland Biomedical Press. Amsterdam (The Netherlands), pp. 117-178

Zimmerman R.A., Scott H.M., 1965. Interrelationship of plasma amino acid levels and weight gain in the chick as influenced by suboptimal and superoptimal dietary concentrations of single amino acids. J. Nutr. 87, 13-18

\section{STRESZCZENIE}

\section{Profil wolnych aminokwasów w plazmie krwi rosnących kurcząt otrzymujących śrutę sojową uzupełnioną DL-metioniną}

Przeprowadzono dwa doświadczenia, których celem było zbadanie wpływu dodatku metioniny do śruty sojowej, przy 4 poziomach białka w diecie, na profil wolnych aminokwasów w plazmie krwi rosnących kurcząt. Zastosowano dwie metody pobierania krwi: jednorazowe pobranie, t.zn. od każdego ptaka pobierano krew jeden raz (doświadczenie 1), wielokrotne - od każdego ptaka pobierano krew co 4 dni (doświadczenie 2). Jedenastodniowe kogutki White Rock, dobierano losowo z par w oparciu o metaboliczną m.c. $\left(\mathrm{W}^{0.75}\right)$, przydzielono do jednej z dwóch izoenergetycznych półsyntetycznych diet zawierających 60, 120, 180 lub $240 \mathrm{~g}$ białka/kg diety, które skarmiano przez 20 dni. Jedyną paszą białkową we wszystkich dietach była śruta sojowa bez- lub z dodatkiem $2 \mathrm{~g} / \mathrm{kg}$ DL-metioniny.

Doświadczenie 1 przeprowadzono na 32 kurczętach, doświadczenie 2 - na ośmiu. Interakcja pomiędzy metodą pobierania krwi a dodatkiem metioniny lub poziomem białka była nieistotna dla większości aminokwasów. Dodatek metioniny zwiększył zawartość metioniny, a obniżał zawartość treoniny, waliny, leucyny i lizyny w plazmie, niezależnie od metody pobierania krwi oraz poziomu białka w diecie (z wyjątkiem braku wpływu metioniny na poziom lizyny u kurcząt na diecie z 24\% białka), nie powodując zmian w poziomie zasadowych aromatycznych aminokwasów. Czterokrotne zwiększenie zawartości białka w diecie zwiększyło poziom argininy, treoniny, waliny i metioniny, niezależnie od metody pobierania krwi oraz dodatku metioniny, przy czym najwięcej (3 krotnie) wzrosła zawartość treoniny.

W podsumowaniu stwierdzono, że dodatek metioniny do śruty sojowej istotnie obniża poziom niezbędnych aminokwasów w plazmie krwi - treoniny, waliny, leucyny i lizyny - rosnących kurcząt, co odpowiada ich wykorzystaniu do syntezy białka oraz w innych procesach anabolicznych. Poziom aminokwasow w plazmie krwi pobranej po karmieniu jest czułą metodą do oceny poprawy jakości diety uzupełnionej metioniną. Także poziom aminokwasów w plazmie zwiększa się proporcjonalnie wraz ze wzrostem pobrania białka, co szczególnie dotyczy treoniny.

Obydwa zastosowane sposoby pobierania krwi okazały się odpowiednie przy ocenie poprawy jakości białka diety uzupełnionej metioniną. 